\title{
Generation of Added Value through the Process of Soft Shell Crab: A Sustainable Development Option in the Coastal Region of Sonora
}

\author{
Luis E. Ibarra ${ }^{1}$, Erika Olivas ${ }^{1}$, A. Lourdes Partida ${ }^{2} \&$ Daniel Paredes $^{3}$ \\ ${ }^{1}$ School of International Trade, Sonora State University, Hermosillo, Sonora, México \\ ${ }^{2}$ School of English Language Teaching, Sonora State University, Hermosillo, Sonora, México \\ ${ }^{3}$ School of Agribusiness Management, Sonora State University, Benito Juarez, Sonora, México \\ Correspondence: Luis E. Ibarra, School of International Trade, Sonora State University, Hermosillo, Sonora, \\ México. Tel: 1-622-948-7708.E-mail:luis.ibarra@ues.mx or luisim00@hotmail.com
}

Received: March 12, $2015 \quad$ Accepted: March 30, $2015 \quad$ Online Published: May 31, 2015

doi:10.5539/jms.v5n2p57 URL: http://dx.doi.org/10.5539/jms.v5n2p57

\begin{abstract}
Nowadays there are fishery resources that have suffered the consequences of overexploitation, pollution or climate change, therefore, the population of marine organisms of commercial importance has diminished noticeably. One of the alternatives to mitigate this reduction, is the diversification of the fishery and aquaculture activity, through value creation.To do this, there is a great number of species to cultivate and that have not been seized due to the lack of interest or knowledge, in addition that the fishery communities have not been provided with the sufficient technology to allow its correct exploitation and leave their comfort zone. In that manner, this article has as a general objective to develop an added value proposal for the commercialization of crabs, through a Soft Shell Crab closed system technical production, for the coastal region of the State of Sonora, in such a way to be taken as a viable option of economic and social growingfor the community, by a sustainable development, the establishment of communication mechanisms and a permanent concentration among the different actors and factors that will constitute the soft crab technical process, acceding the establishment of strategic alliances and commercial agreements for the integration of productive chains with the participation in state and national production programs, with the purpose of product commercialization.
\end{abstract}

Keywords: Commercialization, fishery, Soft Shell Crab, sustainable development

\section{Introduction}

Nowadays there are fishery resources that have suffered the consequences of overexploitation, pollution or climate change; therefore, the population of marine organisms of commercial importance has diminished noticeably (Vega-Villasante, 2006). One of the alternatives to mitigate this reduction is the fishing and aquaculture activity diversification, through value generation. That is the case of the crab, which is captured in the coastal region of the State of Sonora by fishermen who sell it fresh to traders or intermediaries in order to be processed and commercialized as pulp, refrigerated, pasteurized or canned. It is important to mention that only an $8 \%$ to $15 \%$ of the edible portion is used however, a soft crab can be utilized in a 90\% (Sánchez-García \& Hernández-Bernalo, 1995).

Crabs, during the process of carapaces changing, absorbs water that promotes the increasing of size in a period of one or two hours, where the exoskeleton is soft, contains less concentrations of calcium bicarbonate and a higher percentage of water compared to its natural state (hard shell), that permits at the end of the molt process to obtain a selling product with a higher weight and flavor, and a better price (Vega-Villasante, 2006). Soft shell crab production (soft or molted) is a viable aquaculture alternative to give this fishery resource a higher added value.

Examples like the coast of the United States, Gulf of Mexico, coastal region of Veracruz, Tabasco and Campeche, where the soft crab production is a profitable activity using a Callinectes arcuatus or "blue crab" as a basis organism for the process.

The soft crab is obtained from a natural process that the group of crustaceans develop to grow, which is nominated molt or ecdyses and consists in the elaboration of a new cuticle under his old carapace (Ramírez-Garrido \& Hernández-Tabares, 1990) the molting depends of a series of intrinsic and extrinsic factors 
such the age, specie, temperature, salinity, maturity state, alimentation, among others (Monroy-Pulido \& Orellana-Buenrostro, 1998).

One of the goals of this bibliographic investigation is to demonstrate the benefits in the development of the fishery regions in the State of Sonora, through the introduction of technical systems for the production of Soft Shell Crab, as an income sourcecomplimentary to the fishing activity. In this manner, this option of an alternative and complimentary use of the natural marine sources is presented, taking into consideration the semi farming of soft crab as an investment project with short or medium term redemption. In the same way are presented the methodology and the main basis of the technical process for the production of soft crab, from the Callinectes genus.

\section{Material Studied}

At a global level, the native species of Liocarcinus depurator crabs of genus Callinectes Stimpson, 1860, Liocarcinus: Portunidaeare distributed along the European coasts, Japan, Mediterranean's oriental region, West Africa, occasionally in the Pacific, and in both coastal regions and hemispheres of America. In Mexico are registered six species of Callinectes. In the Atlantic littoral are located the blue crab, Callinectes sapidus Rathbun, 1896; the brown crab, Callinectes rathbunae Contreras, 1930; the dwarf crab, Callinectes similis, Williams, 1966. In the Pacific littoral jut the blue crab, Callinectesarcuatus Ordway, 1863; the warrior crab, Callinectes bellicosus Stimpson, 1859, and the giant or black crab, Callinectes toxotes Ordway, 1863.

In the species grouped under the Callinectes genus, the swimming ability is provided by their rear pair of legs that act as paddles. The genus name of Callinectes comes from the Latin Calli= beauty and nectes $=$ swimmer. Besides, the crabs show sexual dimorphism, where the males have a long and slim T-shape abdomen, which in young crab is bounded in its abdomen and in the adult crab, hangs freely; however female crabs are characterized by a triangular abdomen sealed to the body in the young ones; and wide in the mature species. Ovigerous are the female with eggs exposed en their different gonadic stages, as is shown in Figure 1.

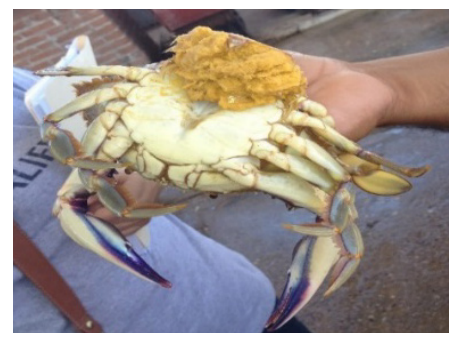

Figure 1. Stage 5: external mass of eggs attached to female's abdomen

The three Callinectes species registered in the Mexican Pacific coast are under the commercial fishery in all the coastal states, due the exquisiteness of its meat. The C. bellicosus is the most important in terms of capture's volume and generates the $95 \%$ of the captures in Sonora, according to the Mexican Secretary of Agriculture, Livestock, Rural Development, Fisheries and Food (SAGARPA, 2013 by its acronym in Spanish).

The national production volume during the period 2002 to 2013 was of 26,878 tons of live weight, which represented a $1.54 \%$ of the national participation in all of the most important fisheries in the country, distinguishing the productions of the states of Sinaloa and Sonora that contributed with a 59.55\% of the total production, holding the first and second place of the national production in that period, with a $42.27 \%$ and $17.28 \%$ respectively as is shown in Graphic 1 (CONAPESCA-SAGARPA, 2014).

For the year 2013, SAGARPA reported a crab's accumulated national capture in the range of 26,878 tons of live weight, that represented a total revenue of $\$ 349652384.00$ pesos, that symbolizes an average value of $\$ 13.00$ pesos per kilogram of crab at a national level. In this regard, can be concluded that the crab production in Sonora during the year 2013 , contributed with $0.266 \%$ of the production earmarked to human consumption, with a captured volume of 4,644 tons, while at a state level, the total reported is 675398 tons of all species earmarked to this type of consumption (CONAPESCA-SAGARPA, 2014). 


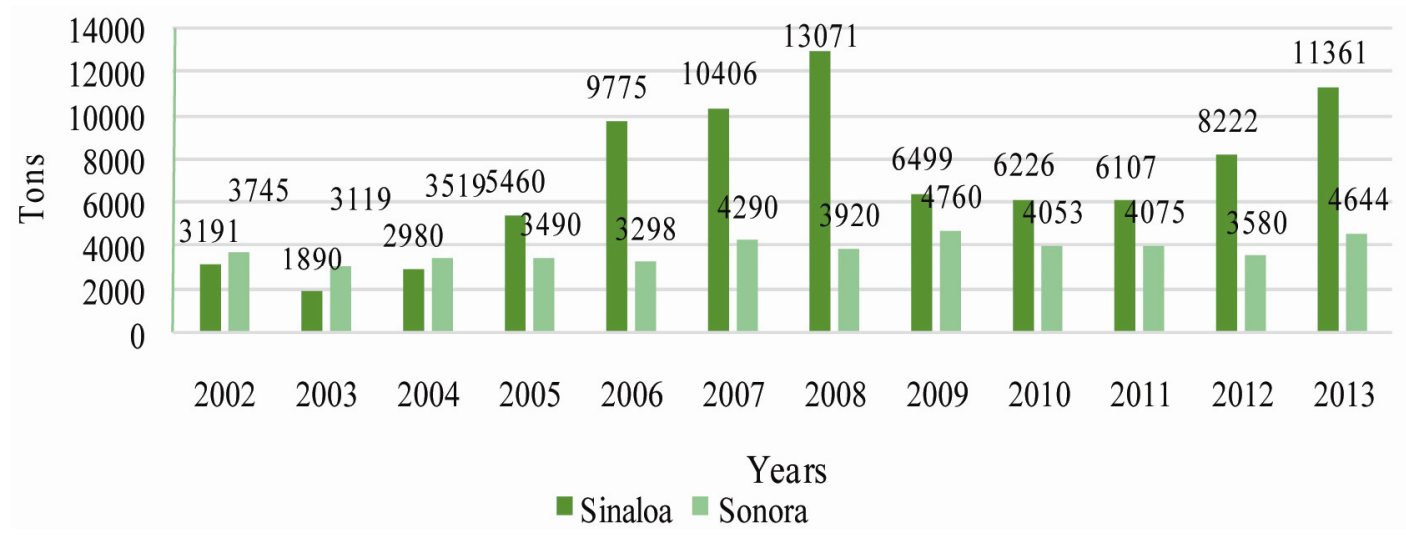

Graphic 1. Crab national production in the states of Sinaloa and Sonora, 2013

\section{Literature Review}

\subsection{Crab Fishery in the State of Sonora}

Sonora state has 12007 kilometers of coastline; 29411 square kilometers of continental platform; 57700 hectares of coastal lagoons and 47084 hectares of reservoirs that favors to provide with the $17.28 \%$ of the national crab fishery production, holding the second place with a sharing to the sector of 4644 tons, and a value of $\$ 53193443.00$ pesos and an average value of $\$ 8.73$ pesos per kilo of crab off the boat (CONAPESCA-SAGARPA, 2013). In marine species productionduring the year 2013, Sonora held a share of $42.36 \%$ (675 398 tons) from the national production, with a value of \$2 610990925.00 pesos attaining the first place in the national capture. The national fishery sector manages about 45500 jobs, distributed among the different phases of the process, as capture 20000 ; industry 15000 ; aquaculture 6500 ; commerce and services 4 000, according to CONAPESCA-SAGARPA (2013). The 2013 Statistical Yearbook points out that in Sonora there are four marine species that are predominant by its capture levels and economical value, as is shown in Graphic 2.

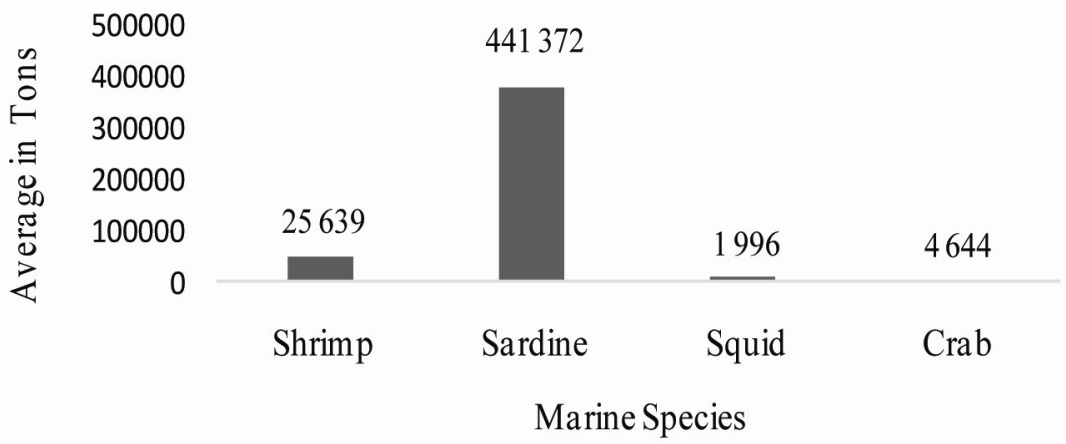

Graphic 2. Main marine species by its capture level in year 2013

Table 1 shows state's indicators in terms of crab capture and value during the period 2007-2013, displaying a diminish in crabs' capture volume, being the most representative the year 2010 compared to year 2009, year 2012 to year 2011, what implies that crab fishery is at its highest sustainability. 
Table 1. Sonora State's indicators of capture and value in pesos, series 2007-2013

\begin{tabular}{lllll}
\hline Year & Live weight in $\mathrm{Kg}$ & Value in pesos & Average $\mathrm{Pv}_{\mathrm{u}}$ & Growth Rate \\
\hline 2007 & 4295801.00 & $\$ 36362040.35$ & $\$ 8.46$ & NA \\
2008 & 3921378.00 & $\$ 37134537.55$ & $\$ 9.47$ & -8.71 \\
2009 & 4766328.00 & $\$ 45273550.89$ & $\$ 9.50$ & 21.54 \\
2010 & 4051638.37 & $\$ 29649971.43$ & $\$ 7.32$ & -14.99 \\
2011 & 4048378.00 & $\$ 43585931.04$ & $\$ 10.77$ & -0.080 \\
2012 & 3586720.20 & $\$ 44897340.00$ & $\$ 12.52$ & -11.40 \\
2013 & 4643636.00 & $\$ 53193443.00$ & $\$ 8.73$ & 29.47 \\
\hline
\end{tabular}

The National Fishery Statement (2012) published by SAGARPA-INAPESCA in the Official Journal of the Federation, dated in August 24, 2012 states the management for the exploitation, protection and the preservation of natural resources, in agreement to Article 27 of the Political Constitution of the Mexican United States, and Article 33 of the General Law of Fishery and Sustainable Aquaculture (LGPAS) by its acronym in Spanish.

However, the Graham-Schaefer model indicates that the maximum sustainable catch (RMS) is reached at the point given by RMS $=r * K / 4$ (Walters y Ludwig, 1994), for this parametric values range, for which the $95 \%$ of crabs caught in Sonora belongs to the genus Callinectes Bellicosus (brown crab). The value or $\mathbf{r}$ represents the organism population intrinsic rate of growth, while $\mathrm{K}$ indicates the index of maximum biomass (Schaefer, 1954).

Registered data reported that the index of maximum biomass in Sonora's stock oscillates between 8800 and 21 600 tons, while the value of intrinsic rate of growth goes from 0.6 to 1.8 (Bertalanffy, 1976). In that manner, Graham-Shaefer model indicates that the RMS for Sonora oscillates between 3240 tons for the case of a large and unproductive stock, and 3960 tons for the case of a small and highly productive stock.

\subsection{Sonora's Port Infrastructure}

Sonora's port infrastructure is distributed in three seaports: Guaymas, Yavaros and Puerto Peñasco, summing a total of 54 piers with a useful berthing length of 3878 meters, distributed as follows:

Paraje Nuevo (Guaymas). With a total of 15 piers, a useful berthing of 926 meters and 33tranches of berth is capable to operate a fleet of 83 sardine boats.

Guaymas. With a total of 25 piers, a useful berthing of 1724 meters and 11 tranches of berth for sardine boats and 57 for shrimp boats is moving a fleet of 60 sardine boats and 342 shrimp boats.

Yavaros (Huatabampo). It holds a five kilometer-length and 40 meter-wide navigation channel, with a useful depth of 4.5 meters, in addition to 8 piers with a useful length of 935 meters. There are tranches of berth for 20 sardine boatsand 7 seven for shrimp boats, and 27 for boats in order to attend a fleet of 18 sardine boats, 42 shrimp boats and 162 smaller vessels.

Puerto Peñasco. Has a 238 meter-length breakwater with rocks as a construction material. It holds an 800 meter-length and 30 meter-wide navigation channel with a useful depth of 3.5 meters. The piers have 25 tranches of berth for shrimp boats and one for fish scaler boat, capable to operate a fleet of 6 fish scaler boats and 150 shrimp boats.

In the state fishery are operating 565 larger boats, from which 523 are shrimp boats and 42 are sardine boats, with an operating average age of 25 years and a riverside fleet of near 8 thousand traditional fishing boats with only 2721 properly registered in the National Registry of Fisheries and Aquaculture (RNPA, 2013). The industrial plant consists of 100 companies that process sardine, crab, shrimp, squid, snail and other mollusks.

\subsection{Fishing Zones}

First, it is important to begin with the investigations done in relation to ecological management for Santa Clara Gulf made by SEMARNAT thatderived from a diagnosis within the management methodologies, which is founded in the analysis of capability from the different fishery sectors involved. This capability analysis is defined as the expression of interests about the natural resources from a specific sector; as well as its relation with the interests formulated by the other sectors in the management zone (SEMARNAT, 2003; Malczewski et al., 1997; Sorensen et al., 1992).

For this study, was pertinent toconsider thecapability analysisof one sector: the riverside fishery; however, the analysis of the rest of the sectors, industrial fishery, tourism and preservation is available at SEMARNAT web page (www.semarnat.gob.mx). The capabilityof each sector is evaluated through models of sensory capability 
which are integrated from the environment factors that define the interests of each sector involved in the management process (Cendrero et al., 2003; Cendrero \& Fischer, 1997).

These models are developed from the theory of environmental indices and indicators (Cendrero et al., 2003; Christie, 2005; Gastelum, 2006) and are built mathematically as a weighted sum of environment attributes representative of the sector's interests considered and identified in the stage of characterization.

Spatially, the analysis takes place at the level of environmental unit (generated in the stage of characterization with the process of regionalization), and an estimated of capability is obtained for each environment unit of the four sectors (riverside fishery, industrial fishery, tourism and preservation), within the context of the Gulf of California.

For the riverside sector, the Sector Aptitude Index (IAPER by its acronym in Spanish) has as a goal to establish an estimated of the interests in the Gulf of California. As foundation the IAPER is based in the following environment attributes (data base) integrated during the stage of characterization (understanding "fishing zone"as the Environment Unit total space where that fishing takes place): Shrimp fishing zone (CAM by its acronym in Spanish), Scale fishing zone (corvina, lisa, snapper, snook, red snapper, sierra) (ESC by its acronym in Spanish), Squid fishing zone (CAL by its acronym in Spanish), Crab fishing zone (JAI by its acronym in Spanish), Shark (coastal and ocean) fishing zone (TIB by its acronym in Spanish), and Bay and Coastal Lagoons zone (Ba by its acronym in Spanish).

The model that represents the capability of the riverside fishery sector is defined by the diversity of fisheries in an Environment Unit and the presence of bays and coastal lagoons. However, in the model is important to consider the social and economic relevance that have each one of the fisheries developing in the region, for which is established a weighing of the index components that represents the relative relevance of each model components. This weighing is defined from an analysis of experts' opinion (Balkey, 1968), through which the weight of each component is determinate in an empirical manner.

Next, the IAPER index is presented in its mathematical form and the weight for each component, according to formula 1 .

$$
I A P E R=C A M(0.5)+E S C(0.2)+C A L(0.1)+J A I(0.1)+T I B(0.07)+B a(0.03)
$$

\subsection{Crab (Callinectes Bellicosus)}

Crab (Callinectes bellicosus), marine specie subject of this study, presents the cephalothorax strongly merged and compressed, in addition, its rear pair of pleopodoare modified for swimmingin water columns. Crabs are distributed along the tropical and warm East Coasts of United States, East and West Coast of Central America, West Africa, South Pacific Islands and West Atlantic. In our country can be found in the Caribbean, Gulf of Mexico and Pacific Ocean (Williams, 1984).

According to Barnes (1996) taxonomically, crabs are animals that belong to phylum Arthopoda, subphylum Crustacea, class Malacostraca, order Decapoda, suborder Pieocyemata, suborder Brachyura and familyPortunidae. This species have a natural longevity of 2 or 3 years. In five weeks, they change from zoea to juvenile. They reach sexual maturity at the age of 12 or 18 months, with an average size of 60 millimeters. (Dittel \& Epifanio, 1984). Adults' cephalothorax (Ac) size goes from 40 to 170 millimeters. The average size for Callinectes bellicosus and Callinectes toxotes is approximately 120 millimeters, while for the Callinectes arcuatus is 90 millimeters.

In Figure 2, is shown the artisanal system for the measuring of minimum sizes, according to what is stipulated in the Official Mexican Norm (NOM-039-PESC-2003). In adulthood males are more abundant than females (relation 2:1) Males are larger and heavier than females in approximately $20 \%$. 


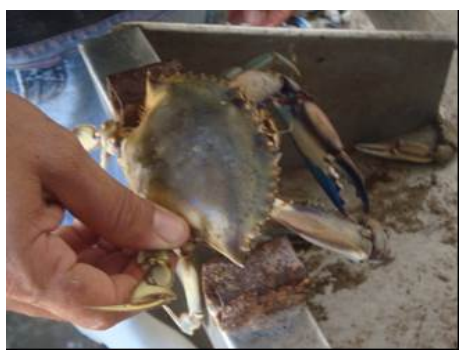

Figure 2. Artisanal system for measuring crabs of minimum size

The Callinectes bellicosus sustains the regional fishery in the Coast of Sonora and part of North of Sinaloa (Molina, 1999; Hernández-Moreno, 2000; Hudson-Weaber et al., 2001; Márquez-Farías, 2001), it is coastal habitats specie, regular size with peaks of abundance increase during the seasonal in the sea temperature (spring and summer) along the state's coast. They are located in environments with a temperature between $18^{\circ} \mathrm{C}$ and $34^{\circ} \mathrm{C}$ and a variable salinity depending on the specie. A crab sample is shown in Figure 3.

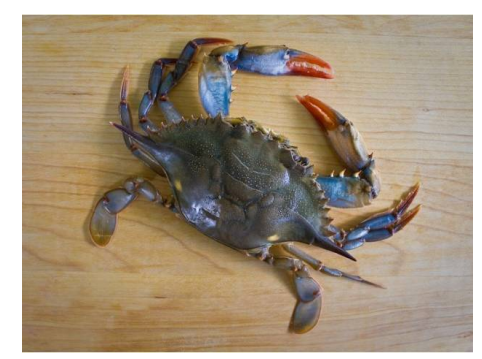

Figure 3. Crab from genus Callinectes, specie bellicosus

Crab's exploitation has been accomplished within the Official Mexican Norm (NOM-039-PESC-2003), which regulates crab's responsible fishing in waters of federal jurisdiction in the Pacific Ocean littoral. The same way establishes the specifications for its exploitation with a purpose to contribute to the responsible handling of crabs' species from a biological point of view.

In that manner, the Mexican Secretary of Agriculture, Livestock, Rural Development, Fisheries and Food (SAGARPA) will establish periods and vetoes zones for crabs' species fishing, during its reproduction and growth. Recent crabs' biological-fishing evaluations made by the National Fishery Institute (INAPESCA, 2012 by its acronym in Spanish) in the Mexican Pacific littoral showed that in Sinaloa and Sonora the main reproductive season takes place from May to August.

\subsection{Soft Shell Crab Production}

The handling of genus Callinectes in the production of soft shell crab (soft or molted) from organisms obtained in its natural environment, outlines a viable alternative aquaculture, to give this fishing resource a higher added value that the one that currently owns. For that reason is of particular interest to publicize the possibility of integrating this aquaculture activity to Sonora State's fishermen.

According to Vega - Villasante (2006), soft shell crab can be summarized in three main kinds: floating cages, open circulation in a terrestrial system and closed circulation in a terrestrial system. Nowadays the largest productions of soft shell crab are carried out in the United States and Southeast Asian countries. In Latin America productions of this species are registered in Mexico, the coast of the Gulf of Mexico; being the United States and Japan the largest consumers.

This marine species of genus Callinectes is which presents the highest grade of adaptability for its culture, since it requires small spaces and low technology and can be realized with a minimum invest (Huner \& Brown, 1985). Due to the fact that in semi cultivation the soft crab (molted) reaches an adequate size for its commercialization, and only requires reaching the process of periodic renovation or molt, either natural or induced, to increase the 
commercial value in the foreign markets. In general, physiologists identify four phases or stages in crabs' molt process, which are presented as follows: postmolt, intermolt, premolt and molt.

The soft shell crab production system has been designed to place crabs, during the molt process, under controlled conditions, that allows its harvest during the few hours in which the carapace is soft, by using this system is pretended to generate an added value to crabs' meet and to its commercialization, utilizing at least $90 \%$ of its meat, generating more jobs and impacting the economy of the state's coastal communities. It can be considered a viable process due to the fishery resources that the different regions of Sonora have, taking as a reference the successful outcomes in United States and Japan, as well as the following Mexican states: Veracruz, Tabasco and Campeche that have been applying this technical production process.

In Table 2 are presented the average daysin which crabs will molt according to the molding stage existing at the moment of catching, as well as its size; it takes some days for larger crabs to complete the molting cycle; while in smaller crabs, the molting is more frequent. The amount of days to reach the molt depends on the regions where crabs are caught, temperature and seasons of the year.

Table 2. Crab's molting average days depending of its size in centimeters (spine sideways)

\begin{tabular}{llllll}
\hline Cm size & Postmolt & Intermolt & Initialpremolt & Intermediatepremolt & Advancedpremolt \\
\hline From 5 to 6 & 25 & 19 & 10 & 5 & 3 \\
From 6 to 7 & 25 & 20 & 10 & 5 & 3 \\
From 7 to 8 & 35 & 30 & 13 & 7 & 5 \\
From 8 to 9 & 40 & 35 & 15 & 10 & 6 \\
\hline
\end{tabular}

\section{Methods and/or Techniques}

More than focusing on a specific methodology, this investigation will show a compilation of previous studies, made in each one of the fishery regions previously cited, with the objective of having a reference frame about the conditions of crab's fishery in Sonora, based on local development sustainability. Criteria and reference points used are economic, social, ecological, and government support or intervention. The study's area covered the three most representative fishery zones in Sonora, being Huatabampo, Guaymas, Bahía de Kino, Puerto Peñasco and Caborca representing the south, center and north of the state.

Basically, information was used to detect potential risks and the areas of opportunity for this fishery activity, which according to SAGARPA and CONAPESCA (2012) is in its maximum sustainable. In this sense, main indicators analyzed are biomass index, capture intervalmaximum sustainable, suggested maximum effort level of catch per unit; economic indicators as catch levels, growing rate, sector exportation, jobs generated and income, just to mention some, with the intention of presenting a viable option of diversification and alternative management, thus a complement of natural marine resources in each of the regions, as a way to improve the income in crabs' producers, considering the semi culture of soft crab as an investment project with a short or medium term investrecover.In addition, are shown the main bases to implement a tech soft shell crab production from genus Callinectes.

\section{Results}

\subsection{Bases and Methodology for the Management of Crab Genus Callinectes Semi Culture}

For the process of soft shell or molted crab, some important points must be taken into consideration to contribute to the success of it.

Regarding zone localization, should be considered the following:

a) To be a permanent source of crab.

b) To be a zone where crab fishery is well developed.

c) To be a place with a good quality brackish water available.

d) To have constant levels of oxygen, $\mathrm{pH}$, temperature, salinity and nitrates.

e) Not to be a zone with abundant muddy waters.

f) With a flow of gentle waves and.

g) With a good disposition and quality of phytoplankton. 
To install the tech operative system in the zone or located area to carry the molt process, Ruiz (1978) suggests taking into account the following:

a) Salinity. It must have a constant salinity and keep it no higher than 5 parts per million (ppm) above and under the area where the premolt crabs are caught.

b) Temperature. The optimum temperature for obtaining a faster molting oscillates between $28^{\circ} \mathrm{C}$ and $36^{\circ} \mathrm{C}$.

c) Oxygen. Oxygen levels must be kept as high as possible, through aeration.

d) Sediment load. The selected area should not have a constant input of muddy waters.

e) Contaminants. The selected area should not be near of possible sources of contamination.

f) Water flow. Should be a constant water flow with shallow waves.

g) Access. Should have an asequible access and be close to the zone in order to be guarded.

\subsection{Catch of Premolt Crab}

Equipment selection for the harvest will determine the quality of the captured crab. For the harvest, the following organism observations should be contemplated (Gutiérrez, 1991; Hartley y Córdova, 1991).

a) The last two segments of the swimming leg and joint legs should be checked to verify if the suture line is present. If the line is pink or purple, molt will take place in a period of 1 to 6 days; if the line is white, the molt will take 6 to 14 days; if the suture is green, molt will present in 5 to 25 days, as is shown in Table 3 .

b) It must be avoided to harvest crabs with a mossy back; since this condition indicates that the crab has not molted for a long period and is possibly due to a hormonal problem.

c) Abdomen coloration, in males, tend to be pale yellow along the abdominal segments, while in females (especially immature) is violet in the triangle.

d) At touch it can be felt that the swim leg is softer and is covered with a viscous fluid.

e) By its size, the weight in premolt crabs is higher.

Table 3. Suture line to know crab's moltingin days

\begin{tabular}{lll}
\hline Sutureline & Molt (\%) & Moltingtime (days) \\
\hline Red & 92 & $1-3$ \\
Pink & 84 & $2-6$ \\
White & 60 & $3-14$ \\
Green & 48 & $5-25$ \\
\hline
\end{tabular}

\subsection{Operative System for the Proposed Semi Culture of Crabs.}

The operative system for the semi culture of soft crab is shown in Figure 6; furthermore, the following elements must be included (Wheaton, 1982):

a) Plastic or fiberglass tubs with these measures: 3 meter-long, 1 meter-wide and 0.25 meter-depth, over a base of 1.30 meter-height. The place must be roofed over and ventilated.

b) One inch PVC pipes, with reducers at half inch and PVC pipe of half inch for the water inlet, PVC pipe of one inch for the water outlet with a height in the tub of 0.15 meters in order not to lose the overall level of water in the tubs.

c) A $3 / 4$ HP pump for water supply, which must be changed five or six times a day, draining through the PVC pipes (slope). A special care must be taken for the PVC outlet pipes to avoid them to get clogged with solid waste.

d) Mesh curtains mosquito nettype, installed around the area where the tubs are located to prevent predation.

\subsection{Crabs Farming}

Farming will be done considering the following aspects (Rees, 1963):

a) Genus. It is not convenient to place males and females together, since this delays the molt process.

b) Premolt stage. It will be done based in the suture lines presented previously on Chart 3, which will facilitate its harvest. 
c) Damaged crabs. Crabs that become damaged during transportation will be parted because they can get a disease.

d) Load capacity. In each tub can be placed up to 200 crabs, to prevent problems with contamination due to its waste, allowing a weekly production between 40 and 60 dozens. It is recommended that during the warm months, the number of crabs in the tubs be reduced.

e) Handling. During harvest, crabs must be handling carefully to avoid its deterioration.

\subsection{Harvesting the Product}

For the harvest of the crabs is recommended to count with (Gutiérrez, 1991):

a) Plastic or metal rings.

b) Plastic bags.

c) One or more freezers.

Through constant observation, at the moment the crab is changing the carapace must be separated with plastic or metal rings to prevent being attacked by other crabs, considering that at this point they are highly vulnerable. Once the molting process is over and after waiting for about 20 minutes, when the organism finishes the absorption, the packing process begins, which is done individually, in transparent plastic bags and is subject to freezing, where they will be in a temperature between $-2^{\circ} \mathrm{C}$ and $18^{\circ} \mathrm{C}$, until its sale. It should be a daily blog of the organisms that go into freezing to classify them according to the day of entry.

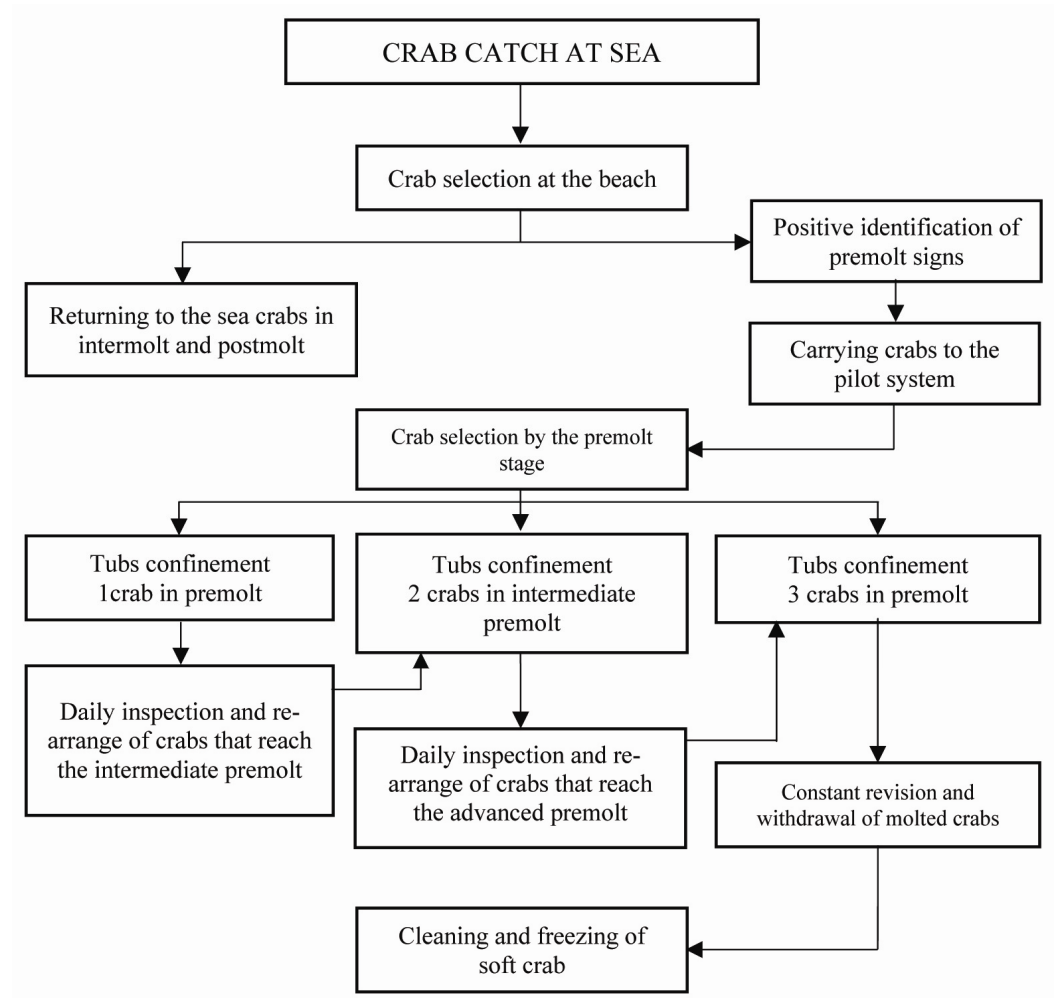

Figure 5. Operation diagram of a system for soft crab production

\section{Conclusion}

The integral exploitation of crabs is a practice with the objective of showing to the coastal fishery sector of Sonora that, from this marine source, added value and high quality products can be obtained. However, crabs exploitation in Mexican Pacific has been kept to sales. In the same way, the lack of knowledge about the process of obtaining soft shell crab in Sonora, makes more attractive be able to offer to the fishermen of the different coastal regions a mean to diversify business options and contribute to towns' economic development. 
The present study shows one of many possibilities that exist to generate added value to crabs, as an example, through a semi culture tech process of soft shell crab, which is attractive due to economic recovery in a short to medium term, thus being considered a process where it is expected for the crabs to molt for rising its price, national and international, having as a reference that soft crab international price is directly related to its size. Price difference between soft crabs and hard shell crabsis incomparable. The added value of soft crabs can overcome in $300 \%$ to $400 \%$ in economic value to hard crabs, being the largest market the United States, where a kilo of soft crab can be paid in $\$ 35.00$ US Dollars.

Production investment is minimal, and will depend on the local prices of supplies and materials required according to the number of crabs to harvest, as well as the number of tubs; also from the available support from government dependencies and private investors. Assuming that an experimental unit requires of two workers for its proper operation, and considering that the critical point in the soft crab production is the daily inspection of the global population and selection of organisms near to molt, the scaling of this production system is viable and will depend on coastal or littoral crab's population. By following the specification that different authors and experts offer related to this process of soft crab semi culture, will assure the success of the project and the contribution to the development of the regions where implemented.

Finally, the local development approach from the environmental and preservation of the marine specie's perspective, catching only the organisms in premolt stage and with a carapace width (Ac by its acronym in Spanish) of at least 8 centimeters, and returning to the sea those species, males and females, in other molt stage, with this the mating and male's spawning will be guaranteed, maintaining the specie's natural balance by not over exploiting it. In such a way, the process by itself, even though has seasonal peaks, can be carried out during the whole year, offering the fishermen alternatives of jobs in other fisheries, as sardines, squid, shrimp, among other activities. Once the process is tested, can be replicated in other coastal zones or regions, whether deterioration of the marine species is present or not. With this will be a contribution to the generalization of sustainable management of crabs in particular, and for the coastal zones habitat.

\section{Acknowledgements}

The authors appreciate the participation of all the people involved in the process of collecting the information, as well as the different fishery cooperatives that support the present project.

\section{References}

Balkey, N. C. (1968). The Delphi method: An experimental study on group opinion. Santa Monica, California: Rand Memorandum 5888 P.R. Rand Corporation.

Barnes, R. (1996). Zoology of invertebrates. Crustaceans (2nd ed.). México, DF. Interamericana ediciones. (In Spanish).

Bertalanffy, L. V. (1976). General Systems Theory. Foundations, development, applications. México, DF: Fondo de Cultura Económica. (In Spanish).

Cendrero, A., \& Fischer, D. W. (1997). A procedure for assessing the environmental quality of coastal areas for planning and management. Journal of Coastal Research, 13(3), 732-744.

Cendrero, A., Del Corral, D., Fermán, J. L., Fischer, D. W., Del Rio, L., Camino, M., \& López, A. (2003). Indicators and indices of environmental quality for sustainability assessment in coastal areas; application to case studies in Europe and the Americas. Journal Coastal Research, 19(3), 919-933.

Christie, P., Lowry, K., White, A. T., Oracion, E. G., Sievanen, L., Pomeroy, R. S., ... Eisma, R. (2005). Key findings from a multidisciplinary examination of integrated coastal management process sustainability. Ocean\& Coastal Management, 48(3-6), 468-483. http://dx.doi.org/10.1016/j.ocecoaman.2005.04.006

Comisión Nacional de Acuacultura y Pesca. (2012). Aquaculture and Fisheries Statistics Yearbooks (Ediciones 2006-2013). Retrieved http://www.conapesca.sagarpa.gob.mx/wb/cona/cona_anuario_estadistico_de_pesca(In Spanish).

Contreras, F. (1930). Contribution to the knowledge of Mexican crabs. Instituto de Biología de la UNAM, 1. (In Spanish).

Cortés-Jacinto, E., \& Vega-Villasante, F. (2009). Soft crab's molt and production in Baja California Sur. El Sudcaliforniano, ciencia, tecnología e innovación para el desarrollo, año, 1(19). (In Spanish).

Diario Oficial de la Federación. Secretaria de Agricultura, Ganadería, Desarrollo Rural, Pesca y Alimentación, Diario Oficial de la Federación, (16 de marzo de 1994). [Notice that is given to know the establishment of 
seasons and areas closed to fishing for different species of aquatic wildlife in waters of federal jurisdiction of the United States of Mexico]. (In Spanish).

Diario Oficial de la Federación. Secretaria de Agricultura, Ganadería, Desarrollo Rural, Pesca y Alimentación, Diario Oficial de la Federación, (11 de junio de 2012). [Agreement amending the notice that is given to know the establishment of seasons and areas closed to fishing for different species of aquatic wildlife in waters of federal jurisdiction of the United States of Mexico].

Dittel, A. I., \& Epifanio, C. E. (1984). Growth and development of the portunid crab Callinectes arcuatus Ordway: zoea, megalopae, and juveniles. Journal of Crustacean Biology, 4(3), 491-494. http://dx.doi.org/10.2307/1548044

Food and Agriculture Organization. (2012). Anuario Estadístico de Pesca y Acuicultura, 2012, publicado por el Departamento de Pesca y Acuicultura de la FAO. Retrieved from http://www.fao.org/fishery/publications/yearbooks/en

Food and Agriculture Organization. (2012). Anuario Estadístico de Pesca y Acuicultura, 2012, publicado por el Departamento de Pesca y Acuicultura de la FAO. Retrieved from $\mathrm{http}: / / \mathrm{www}$.fao.org/fishery/publications/yearbooks/en

García Gastelum, A., Fermán Almada, J. L., Arredondo García, M. C., Cruz Varela, J. A., Galindo Bect, L. A., \& Seingier, G. (2006). Environmental planning model of ecological regulation of the coastal zone from environmental indicators. Latinoamericana Aula y Ambiente del Instituto Pedagógico de Caracas, Venezuela. (In Spanish).

Gutiérrez, M. (1991). Preliminary evaluation of the application of different techniques of ablation for obtaining soft crab Callinectes sapidus Rathbun (decapoda portunidae) (Unpublished Master's thesis). Instituto Tecnológico del Mar, Veracruz, México. (In Spanish).

Hartley, J., \& Cordova, G. (1991). Design, operation and maintenance of a salt water recirculation system (Unpublished Master's thesis), Universidad Veracruzana, México. (In Spanish).

Hernández-Moreno, L. G., \& Arreola-Lizárraga, J. A. (2000). Conceptual model about Green Crab ecology, Callinectes bellicosus, in the coastal lagoons of the state of Sonora, México. Informe Técnico CIBNOR, Unidad Guaymas, México. (In Spanish).

Hudson-Weaver, A., Torre-Cosío, J., \& Bourillón-Moreno, L. (2001). [Green Crab, Callinectes bellicosus, fishing áreas in Bahía Kino and Canal del Infiernillo, Sonora]. Cap. 4, pp. 20-24. En: Montemayor-López, G. y J. Torre-Cosío (Eds.). [Green crab (Callinectes bellicosus) functional management unit, description of biological and social aspects, and fishery management in Bahía Kino and Canal del Infiernillo, Sonora]. CIMEX, A.C. Programa Golfo de California, México. 62 p. (In Spanish).

Huner, J., \& Brown, E. (Eds.). (1985). Crustacean and Mollusk Aquaculture in the United States. AVI Book, EUA. http://dx.doi.org/10.1007/978-1-4684-1503-2

Instituto Nacional de la Pesca. (2012). Carta Nacional de Pesca, (Ediciones 2006-2013). Retrieved from http://www.inapesca.gob.mx/portal/documentos/publicaciones/CARTA\%20NACIONAL\%20PESQUERA/ 24082012\%20SAGARPA.pdf

Instituto Nacional de la Pesca. (2014). Retrieved from http://www.inapesca.gob.mx

Jaibver. (2014). Equipment for soft crab's production. Retrieved from $\mathrm{http}: / /$ maquinas-agricolas.vivanuncios.com.mx/equipo-agricola+boca-del-rio/venta-de-equipo-para-pro duccion-de-jaiba-blanda/84695054 (In Spanish).

Ludwig, D., Hilborn, R., \& Walters, C. (1994). Uncertainty, Resource Exploitation, and Conservation: Lessons from history. Science, 260(5104), 17-36. http://dx.doi.org/10.1126/science.260.5104.17

Malczewski, J., Pazner, M., \& Zaliwska, M. (1997). GIS-based techniques for visualizing multicriteria location analysis: a case study. Cartography and Geographic Information Systems, (24), 80-90. http://dx.doi.org/10.1559/152304097782439367

Márquez-Farías, J. F. (2001). Green crab population status, Callinectes bellicosus, of Bahia Kino and Canal del Infiernillo, Sonora. Cap. 6, pp. 33-41. En: Montemayor-López, G. y J. Torre-Cosío (Eds.). [Functional unit of green grab fishery and description of the biological, economic, social aspects and fishery management of green crab (Callinectes bellicosus) in Bahía Kino and Canal de Infiernillo, Sonora]. CIMEX, A.C. Programa Golfo de California, México. 62 p. (In Spanish). 
Molina, R. E. (1999). Crab fishery in the coast of Sonora. Boletín Pesca y Conservación, 3(7), 6-8. (In Spanish).

Monroy-Pulido, S., \& Orellana-Buenrostro, M. (1998). Crab: species with a great potential of exploitation. Memorias II Simposio Internacional de Acuacultura. Mazatlán Sinaloa, México. (In Spanish).

Ramírez-Garrido, J., \& Hernández-Tabares, I. (1990). Obtaining soft crab Callinectes spp, in wooden floats in Alvarado, Veracruz. Acuavisión, 20(4), 27-31. (In Spanish).

Rathbun, M. (1930). The cancroid crabs of America of the families Euryalidae, Portunidae, Atelecyclidae, Cancridae and Xanthidae. Bulletin U.S. Nat. Mus., (152). http://dx.doi.org/10.5479/si.03629236.152.i

Rees, G. (1963). Edible crabs of the United States, Washington, D.C. Edition United States Department of the Interior Fish and Wildlife Service. Washington, D.C.

Registro Nacional de Pesca y Acuacultura. (2013). Comisión Nacional de Acuacultura y Pesca. [Data Base]. Retrieved from http://www.conapesca.sagarpa.gob.mx/wb/cona/consulta_especifica_por_rn(In Spanish).

Ruiz, M. F. (1978). Fishery resources in the Coasts of Mexico. Ed. Limusa, México. (In Spanish).

Sánchez-García, B. E., \& Hernández-Bernal, J. B. (1995). Quality control in the crab's soft shell production systems. Memorias del II Congreso Nacional de Ciencia y Tecnología del Mar. San Carlos, Guaymas, Sonora, México. (In Spanish).

Schaefer, M. B. (1954). Some aspects of the dynamics of Populations important to the Management of Commercial Marine Fisheries. Bulletin of the Inter-American Tropical Tuna Commission, (1), 25-56.

Secretaría de Agricultura, Ganadería, Desarrollo Rural, Pesca y Alimentación. (2012). Norma Oficial Mexicana NOM-039-PESC-2003. Crab responsible fishery in federal jurisdiction waters in the Pacific Ocean littoral. Specifications for its use. Diario Oficial de la Federación, 11 de junio de 2012. (In Spanish).

Secretaría de Agricultura, Ganadería, Desarrollo Rural, Pesca y Alimentación. (2006). Norma Oficial Mexicana, NOM-039-PESC-2003. Crab responsible fishery in federal jurisdiction waters in the Pacific Ocean littoral. Specifications for its use. Diario Oficial de la Federación, 26 julio de 2006. (In Spanish).

SEMARNAT. (2003). Guide for the presentation of the environmental impact statement Fishery Activity, Regional Modality. Subsecretaría de Gestión para la Protección Ambiental, Secretaría del Medio Ambiente y Recursos Naturales. (In Spanish).

Sorensen, J. C. (1997). National and International Efforts at Integrated Coastal Management: Definitions, $\begin{array}{lllll}\text { Achievements and } & \text { Lessons. }\end{array}$ http://dx.doi.org/10.1080/08920759709362308

Sorensen, J. C., McCreary, S. T., \& Brandani, A. (1992). Coast: Institutional arrangements for managing environments and coastal resources. Coastal resources Center, Rhode Island University.

Vega Villasante, F. (2006). Technical manual for the production of soft crab in the Mexican Pacific. Universidad de Guadalajara. Centro de Universitario de la Costa. (In Spanish).

Wheaton, F. (1982). Aquaculture. Systems' design and construction. AGT Editor, S.A., México D.F. (In Spanish). Williams, A. B. (1974). The swimming crabs of the genus Callinectes. Fisher Bulletin, (72), 685-798.

\section{Copyrights}

Copyright for this article is retained by the author(s), with first publication rights granted to the journal.

This is an open-access article distributed under the terms and conditions of the Creative Commons Attribution license (http://creativecommons.org/licenses/by/3.0/). 